Uluslararası Mühendislik

Cilt/Volume:12 Sayı/Issue:1 Ocak/January 2020

\title{
The Effects of TIG Welding Rod Compositions on Phase Distributions and Corrosion Properties of Dissimilar 304L and 420 Stainless Steel Welds
}

\author{
Mustafa Gökhan Murat ${ }^{1}$ iD , Aziz Barış Başyiğit *2 iD \\ ${ }^{I}$ Naval Training and Education Command, Turkish Naval Forces, 34676, Istanbul, TURKEY \\ ${ }^{2}$ Department of Metallurgical and Material Engineering, Faculty of Engineering, 71450 Kirlkkale, TURKEY
}

Başvuru / Received: 07/09/2019

Kabul / Accepted: 09/10/2019

Çevrimiçi Basım / Published Online: 04/11/2019

Son Versiyon/Final Version: 31/01/2020

\begin{abstract}
304L austenitic and 420 martensitic stainless steels are demanded in wide range of industries. 304L alloy exhibits good resistance to oxidizing medias up to $760^{\circ} \mathrm{C}$ and they also maintain superior impact properties at cryogenic temperatures while 420 alloy provides the strength values close to tool steels in with satisfactory corrosion properties in ambient atmospheres.

In this work; 420 plate is TIG (Tungsten Inert Gas) welded with 304L plate with both thicknesses of 3 mm. Welding operation is applied by two passes under pure argon gas also with shielding the weld root. 3 types of TIG welding rods; ER312, ER316L and ER2209 are used in TIG welding for ensuring 3 different weld metal compositions. The effects of TIG welding rod type on weld metal phase ratios with microstructural and corrosion properties are investigated. Microstructural inspections and corrosion (weight loss) tests are applied to all joints after welding operations.
\end{abstract}

The sample joined by ER312 TIG rod transformed the weld metal into dendritic microstructure and the sample joined by ER2209 TIG rod resulted in globular type of weld metal microstructure. The specimen that welded by ER316L type TIG welding rod resulted in the best corrosion test values among all welded samples.

\section{Keywords}

“420 and 304L stainless steels, TIG welding, phase analysis, corrosion of stainless steels” 


\section{Introduction}

Martensitic stainless steels are demanded in industries where high strength values are desired close to transformation hardenable steels with satisfactory corrosion resistance properties under ambient atmospheres. Common applications include; steam, gas and jet engine turbine blades at low temperatures, pipes, hydro-turbines, freshwater implements and petroleum industries (Lippold \& Kotecki, 2005).

Austenitic stainless steels are preferred particularly for their high impact properties at cryogenic and high temperatures and they exhibit superior corrosion resistance to oxidation in wide range of applications except sea water. Extensive usage fields include especially house wares, medical products, heat treating baskets and furnace inner parts (Lippold \& Kotecki, 2005; ASM Vol. 2, 2005).

In this work; joining of dissimilar 420 and 304L stainless steels are studied by TIG fusion welding method with three different TIG welding rods. Joining of these two types of stainless steels by fusion welding methods requires precautions related with weld metal properties (Lippold \& Kotecki, 2005; ASM Vol. 2, 2005; Kou 2002; ASM Vol. 4, 1991; ASM Vol.6, 1993). Welders have to be aware about problems related with loss of corrosion properties due to the weld metal compositions. Researchers studied about welding of 304L and 420 separately with other types of steels but dissimilar joining of 304L alloy to 420 alloy by TIG fusion welding method is not reported (Dey et al. 2009; Soltani et al., 2018;Khan et al., 2012; Kumar et al., 2017). The welded samples metallographic studies are applied as indicated in literature (Lippold \& Kotecki, 2005; ASM Vol. 4. 1991; ASM Vol. 6 1993; George et al., 2004). As proposed by researchers, brittle chromium rich precipitates may form and worsen the corrosion properties of these high alloyed steels in welding operations (Lippold \& Kotecki, 2005; ASM Vol. 6. 1993; Jiang et al., 2006; Singh\& Shahi 2018; ASM Vol. 13-A 2003; Pierre \& Roberge, 2000]. Hence, corrosion test is applied on all welded specimens Corrosion test is based on weight loss difference principle by keeping samples in solution as indicated in ASTM G48, ASTM G1 and ASTM G31 standards (ASTM G48, 2015;,ASTM G1, 2017; ASTM G31, 2012). Microstructural image analysis is applied for estimating the phase distributions along the weld centerline and also on unwelded base metals according to ASTM E562, ASTM E1245 standards respectively (ASTM E562, 2011; ASTM E1245). Magnetic phase analysis is studied according to ISO 8249 and ISO 17655 standards for ensuring and comparison of the microstructural image analysis test results (EN ISO 8249, 2000; EN ISO 17655, 2003). Anton Schaefflers phase prediction diagram is also used for comparison of phase analyzing methods among each other [Lippold \& Kotecki, 2005; ASM Vol. 6, 1993).

\section{Experimental}

AISI/SAE 420 martensitic (UNS S42000) and AISI/SAE304L (UNS S30403) austenitic stainless steels are prepared for joining by TIG welding.

The chemical composition of both base metals from spectral analysis by AMETEK Spectromax Optical Argon Emission Spectrometer are given in Table 1. ER312, ER316L and ER 2209 coded TIG welding rod chemical compositions from the TIG Rod manufacturers' datas verified within the limits according to standards (AWS A5.9, 2017; EN ISO 14343, 2017) as listed in Table 1.

Table 1. Spectral analysis of 304L, 420 stainless steel plates and manufacturers compositions of TIG welding rods

\begin{tabular}{c|c|c|c|c|c|c|c|c|c|c|c|c|c|c}
\hline Material & $C$ & $S i$ & $M n$ & $P$ & $S$ & $C r$ & $M o$ & $N i$ & $V$ & $N$ & $F e$ & $C u$ & Others \\
\hline 304L & 0.027 & 0.381 & 1.19 & 0.021 & 0.003 & 18,22 & 0.054 & 8.01 & 0.202 & 0.069 & 71.6 & -- & 0.322 \\
420 & 0.231 & 0.504 & 0.629 & 0.013 & 0.002 & 13.34 & 0.0067 & 0.138 & 0.042 & 0.022 & 84.9 & -- & 0.172 \\
ER312 & $<0.15$ & 0.4 & 1.6 & 0.030 & 0.030 & 30.7 & 0.20 & 8.8 & -- & -- & B1. & 0.14 & -- \\
ER316L & $<0.01$ & 0.4 & 1.7 & 0.030 & 0.030 & 18.2 & 2.6 & 12 & -- & 0.04 & B1. & 0.10 & -- \\
ER2209 & $<0.01$ & 0.5 & 1.5 & 0.030 & 0.030 & 22.7 & 3.2 & 8.5 & -- & 0.17 & B1. & 0.01 & -- \\
\hline
\end{tabular}

The dimensions of specimen couples and welded samples are shown in Figure 1.

420 martensitic stainless steel plates are heat treated at $300{ }^{\circ} \mathrm{C}$ for 45 minutes of time period one by one just before each welding operation separately. 304L stainless steel plates were not pre-heated as austenitic groups are not transformation hardenable. 

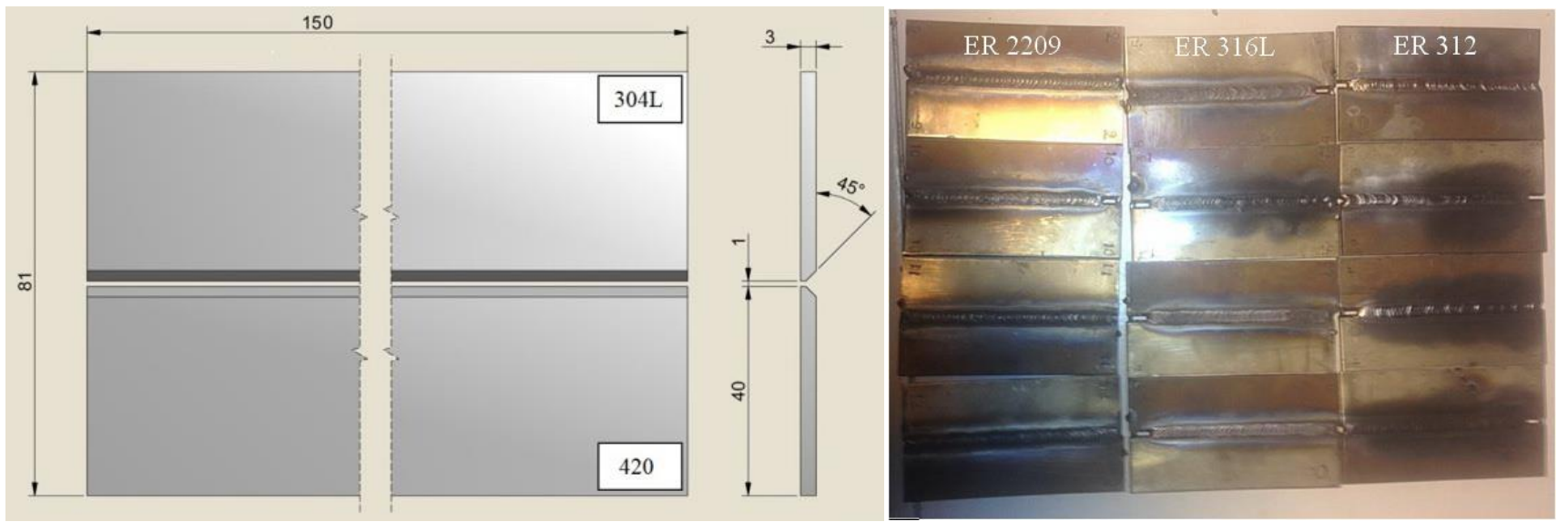

Figure. 1. The dimensions of welded samples

TIG welding is maintained by ESAB TIG 4300i/AC/DC machine. TIG welding parameters are listed in Table 2.

Table 2. TIG welding parameters

\begin{tabular}{|c|c|c|c|c|c|c|c|c|}
\hline \multirow{2}{*}{$\begin{array}{c}\text { TIG Rod } \\
2.0 \\
\emptyset \mathrm{mm}\end{array}$} & \multicolumn{2}{|c|}{$\begin{array}{l}\text { Welding Current } \\
\text { DC- (Amperes) }\end{array}$} & \multicolumn{2}{|c|}{$\begin{array}{c}\text { Welding Voltage } \\
\text { (Volt) }\end{array}$} & \multicolumn{3}{|c|}{$\begin{array}{l}\text { \%100 Argon Shielding } \\
\text { Gas Flow (1/min) }\end{array}$} & \multirow{2}{*}{$\begin{array}{c}\begin{array}{c}\text { Welding Speed } \\
(\mathrm{mm} / \mathrm{sec} .)\end{array} \\
2^{\text {nd. }} \\
\text { Pass }\end{array}$} \\
\hline & $\begin{array}{l}\text { Root } \\
\text { Pass }\end{array}$ & $\begin{array}{l}2^{\text {nd. }} \\
\text { Pass }\end{array}$ & $\begin{array}{l}\text { Root } \\
\text { Pass }\end{array}$ & $\begin{array}{c}2^{\text {nd. }} \\
\text { Pass }\end{array}$ & $\begin{array}{l}\text { Root } \\
\text { Pass }\end{array}$ & $\begin{array}{l}2^{\text {nd. }} \\
\text { Pass }\end{array}$ & $\begin{array}{l}\text { Root } \\
\text { Pass }\end{array}$ & \\
\hline ER 312 & \multirow{3}{*}{70} & \multirow{3}{*}{93} & \multirow{3}{*}{9} & \multirow{3}{*}{11} & \multirow{3}{*}{10} & \multirow{3}{*}{6} & 2.33 & 2.16 \\
\hline ER 316L & & & & & & & 2.29 & 2.18 \\
\hline ER 2209 & & & & & & & 2.25 & 2.20 \\
\hline
\end{tabular}

Pure Argon is used as shielding gas in welding operations. The specimen couples are also shielded by argon gas from their root sides. TIG welding operation is applied in two passes. The net heat input is estimated for both of the weld passes by using $\left(\mathrm{H}_{\text {net }}\right)$ equation (Kou, 2002;ASM Vol. 6. 1993).

Hnet $=(\eta \times \mathrm{E} \times \mathrm{I}) / V$

The symbols; ' $\eta$ ' indicates welding efficiency, E; welding voltage (volts), I: welding current (Amperes), V; welding speed (mm/seconds). ' $\eta$ ' value is 70\% (0.7) in TIG welding application for DC(-) current type (Kou, 2002). $\mathrm{H}_{\text {net }}$ values are estimated for both root and $2^{\text {nd }}$ (final) passes separately.

$\mathrm{H}_{\text {net-root-pass }}=(0.7 \times 9 \mathrm{~V} \times 70 \mathrm{~A}) /(2.33 \mathrm{~mm} / \mathrm{sec})=189$ joule $/ \mathrm{mm}$

$\mathrm{H}_{\text {net-2 }}{ }^{\text {nd }}$ (final)pass $=(0.7 \times 11 \mathrm{~V} \times 93 \mathrm{~A}) /(2.15 \mathrm{~mm} / \mathrm{sec})=333 \mathrm{joule} / \mathrm{mm}$

After welding operation all welded samples are heat treated for stress relieving at $360{ }^{\circ} \mathrm{C}$ for 45 minutes in a dry resistance furnace. After post-weld heat treatment, welded samples are machined for microstructural inspections and corrosion tests in a way according to ISO 15614-1 standard (ISO 15614-1, 2017).

Microstructural investigations are applied on samples after electrolytically etching in $20 \% \mathrm{NaOH}$ solution under 1.6 amperes of current. Micrographs are taken by Leica Brand DM 4000M model optical microscope under 100 $\mu \mathrm{m}$ scale of magnification. Phase distributions of weld metals on each samples are investigated by Schaeffler diagram, Image (microstructural) Analysis and Magnetic Phase testing methods. Anton Schaeffler-1949 diagram basically focuses on equations estimating chromium and nickel equivalents (Cr. eq, Ni. eq.) by weights in percentage. Schaefflers chromium and nickel equivalents by weight for base and weld metals and 3 different TIG rods in percentages are estimated according to Equations 2 and 3 below (Lippold \& Kotecki, 2005; ASM Vol. 6, 1993).

Schaefflers' Chromium Equivalent;

Cr.eq. $=\mathrm{Cr} \%+\mathrm{Mo}+\% 1.5 \times \mathrm{Si}+0.5 \times \mathrm{Nb}$

Schaefflers' Nickel Equivalent; 
Ni.eq. $=N i \%+30 \times C \%+0.5 \times M n$

The results of Chromium and Nickel Equivalents for base metals, weld metals and TIG rods are substituted onto the Schaefflers diagram for predicting the phases. Image analysis is applied on electrolytically etched base metals and welded samples weld metal zones by Carl Zeiss Jena Brand optical microscope under 100x magnified microstructures. The 'Kameram' licensed software is used for image analysis estimations in laboratory according to ASTM E1245 and ASTM E562 standards.

Magnetic phase detection test is also applied on all samples. 420 and 304L base metals and also 3 different weld metals phase distributions are also determined by magnetic phase analyzing technique. The method principally depends on detecting ferromagnetic phases e.g. delta-ferrite, martensite by a probe. All magnetic phases in the other non-magnetic structure are measured. In addition to delta ferrite, martensite and other ferromagnetic phases are also taken into total account. Nevertheless, carbides like chromium carbides contribute the pinning magnetic domain wall movements of structures so that their presence in structure results in poor magnetic properties (Douglas \& Dietrich, 1997).

The magnetic estimations of phases are applied according to AWS A4.2, EN ISO 17655 and EN ISO 8249 standards. Magnetic phase analyzer device Ferritetester SP 10 -a has a probe diameter of $10 \mathrm{~mm}$. The accuracy of Ferritetester SP-10-a is $\pm 2 \%$ up to $30 \%$ and $\pm 3 \%$ up to $80 \%$ by volume of magnetic phases. The uncertanity value of device is approximately $\pm 0.4 \%$.

Magnetic phase analyzing instrument, apparatus and measurement schedule are shown in Figure 2.
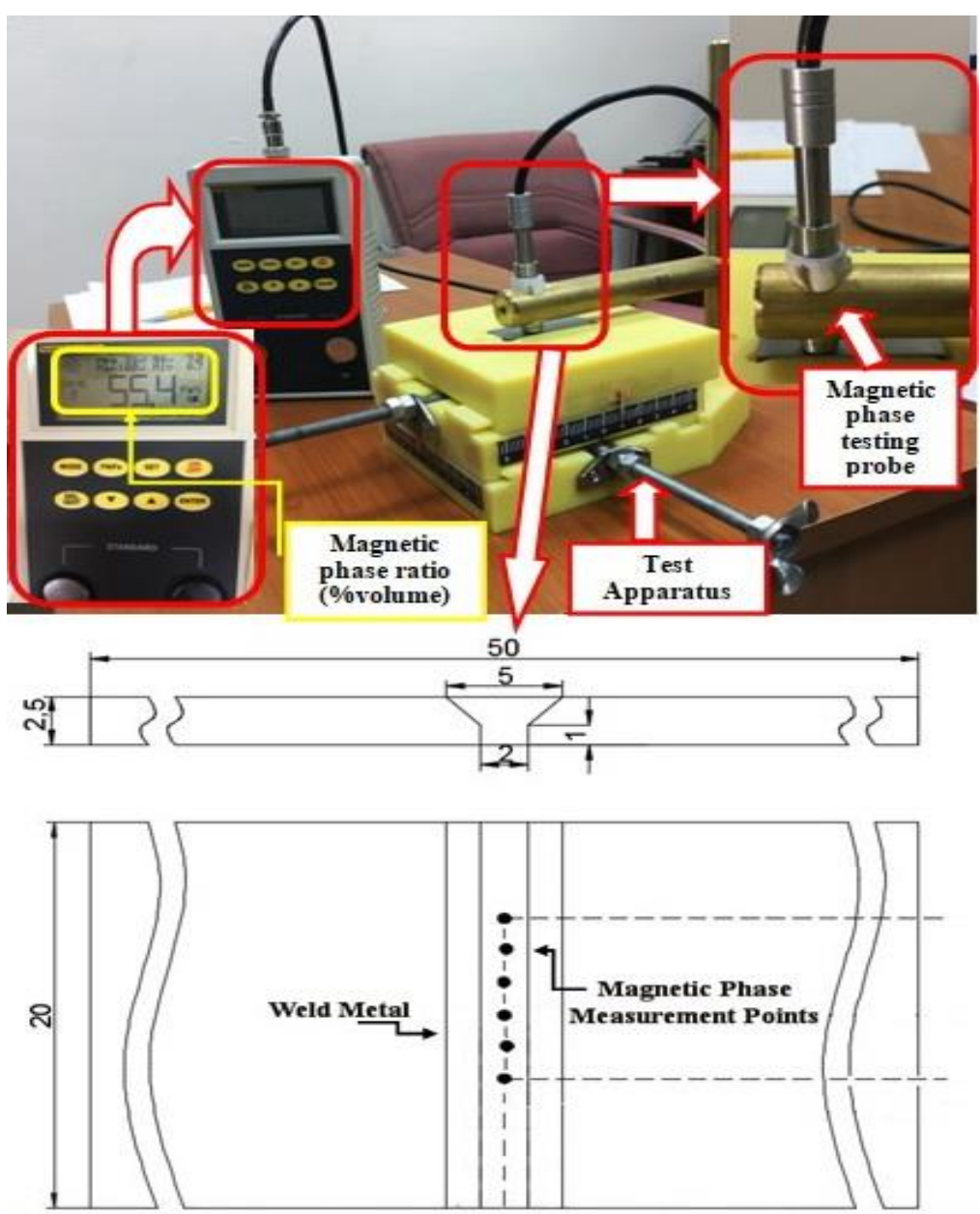

Figure 2. Magnetic phase inspection on welded samples

Corrosion (weight loss) tests are applied on all welded samples according to ASTM G31, ASTM G48 and ASTM G1 standards. Three separate corrosion test samples per each welding condition (per TIG rod type) are used in corrosion tests.

Samples in dimensions of $2.5 \times 20 \times 50 \mathrm{~mm}$ are grinded uniformly for corrosion tests. Length, width and thickness dimensions of samples are measured by a caliper. The thickness values of samples are measured from 3 different points throughout the full length for ensuring more precise values.

The corrosion test is based on weight loss principle by exposure of welded samples to test solution as they react with the solution. Therefore all of the samples are weighed by a $0.0001 \mathrm{~g}$ precision scale before and after the tests. For ensuring the results, every corrosion test sample is weighted by 3 separate times at $22{ }^{\circ} \mathrm{C}$ within the same laboratory testing conditions. Weights of all corrosion test samples before the test are calculated for each sample. Corrosion test liquid is prepared from $\mathrm{FeCl}_{3} \cdot 6 \mathrm{H}_{2} \mathrm{O}+\mathrm{H}_{2} \mathrm{O}$ solution (100 g reagent grade ferric chloride in $900 \mathrm{~mL}$ reagent water) with adjusting the $\mathrm{PH}$ values approximately to 1.3 . The 
samples are immersed in solution during 72 hours of time at $22{ }^{\circ} \mathrm{C}$ and then immediately cleaned from oxidation residuals with brushing and rinsed by pure water and finally with alcohol. Lastly samples are dried by hairdryer.

\section{Results and Discussion}

\subsection{Microstructural Investigations}

Micrographs of base metals

304L and 420 base metals micrographs are investigated. Microstructure of 420 martensitic stainless steel base metal is given in Figure 3.-(a). The darkest (black points or areas) phase is chromium rich carbides, dark phases are martensite and white (bright) phase is delta-ferrite in raw unwelded 420 stainless steel base metal. Microstructure of 304L austenitic stainless steel base metal is showed in Figure 3-(b). White (brighter) phase is austenite and darker phase (like dots) is grain boundary ( $\delta$ ) delta-ferrite in raw unwelded 304L stainless steel base metal. Delta ferrite has the same micro structural properties and crystallographic structure like ferrite but it has been assigned as high temperature ferrite in steels (Lippold \& Kotecki, 2005; George F. et all, 2004).
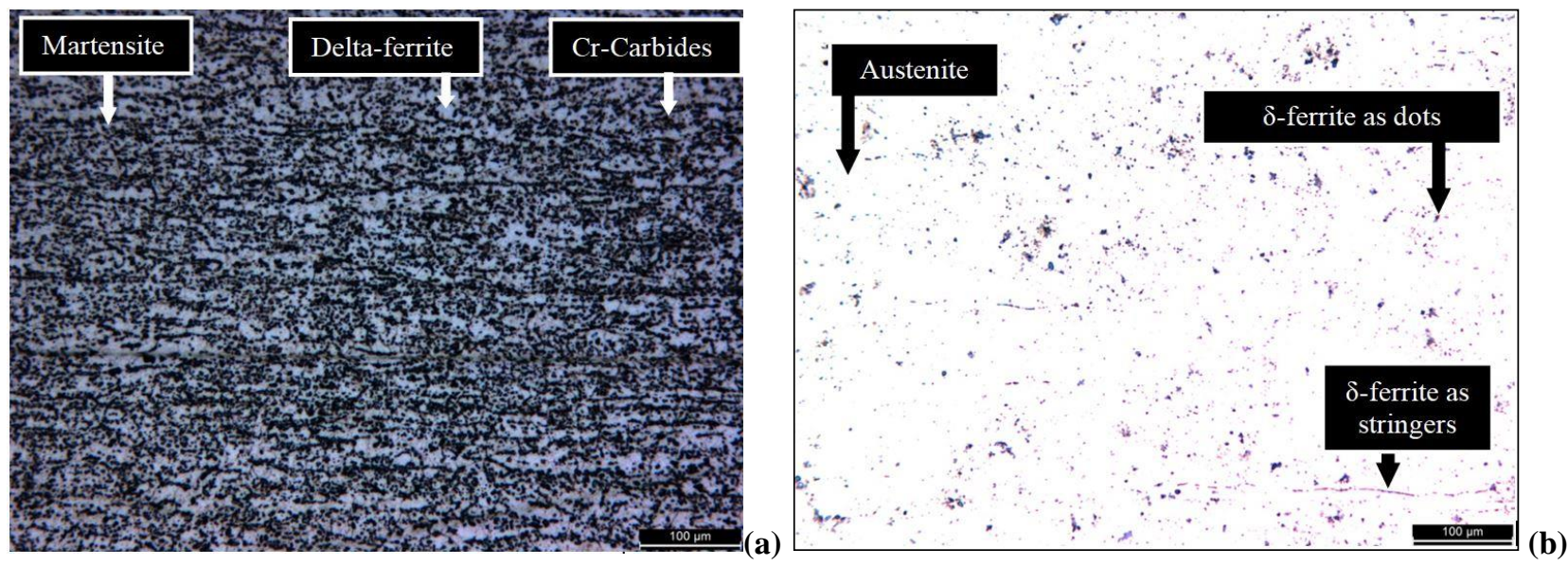

Figure 3. Microstructures of (a) 420 and (b) 304L base metals.

Micrographs of welded samples

Weld metals of each welding condition were investigated in joints.

Micrographs of samples welded by ER312 TIG rod

Microstructures of samples welded by ER312 TIG rod are given in Figure 4. Bright phase is delta-ferrite and the dendritic phase is austenite.

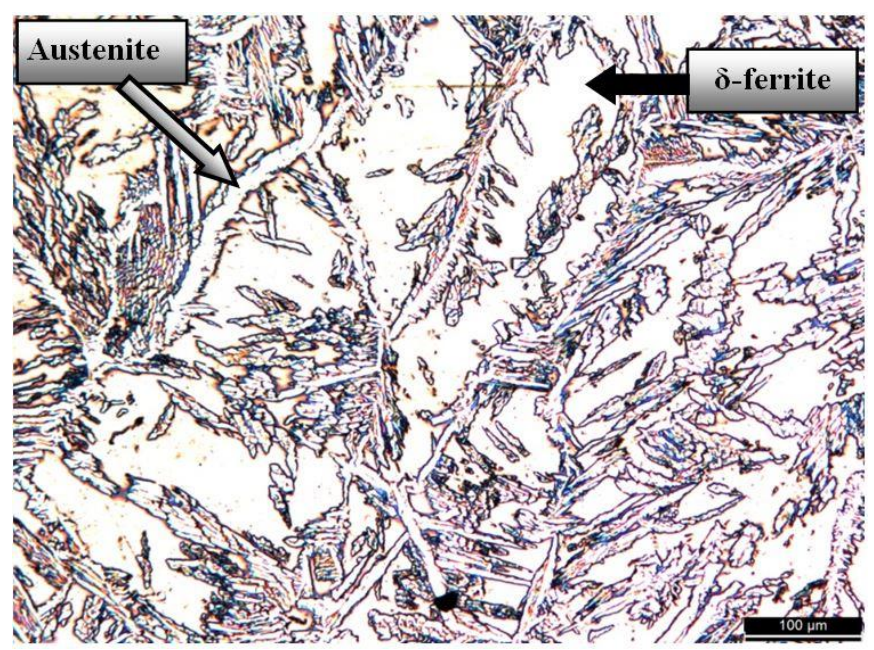

Figure 4. Weld metal microstructure of sample joined by ER312 TIG Rod

Micrographs of samples welded by ER316L TIG rod

Microstructures of samples welded by ER316L TIG rod are given in Figure 5. The dark fields are grain boundary delta ferrite phase and brighter (white) fields indicates the austenite phase. 


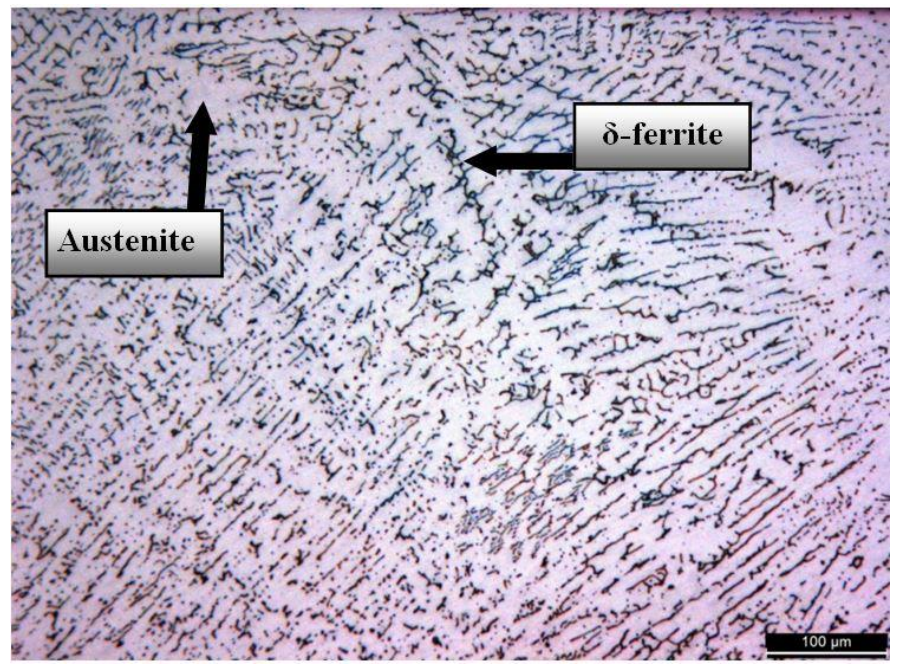

Figure 5. Weld metal microstructure of sample joined by ER316L TIG Rod

In consequence of using ER316L TIG welding rod, the dominant austenite phase with a minority of delta-ferrite is observed.

Micrographs of samples welded by ER2209 TIG rod

Microstructures of samples welded by ER2209 TIG rod are given in Figure 6. In Figure 6, as compared to the Figure 5, there has been no major differences noted. Hence, especially in Figure 6, the weld metals delta ferrite seemed like more globular structure besides to Figure 5 .

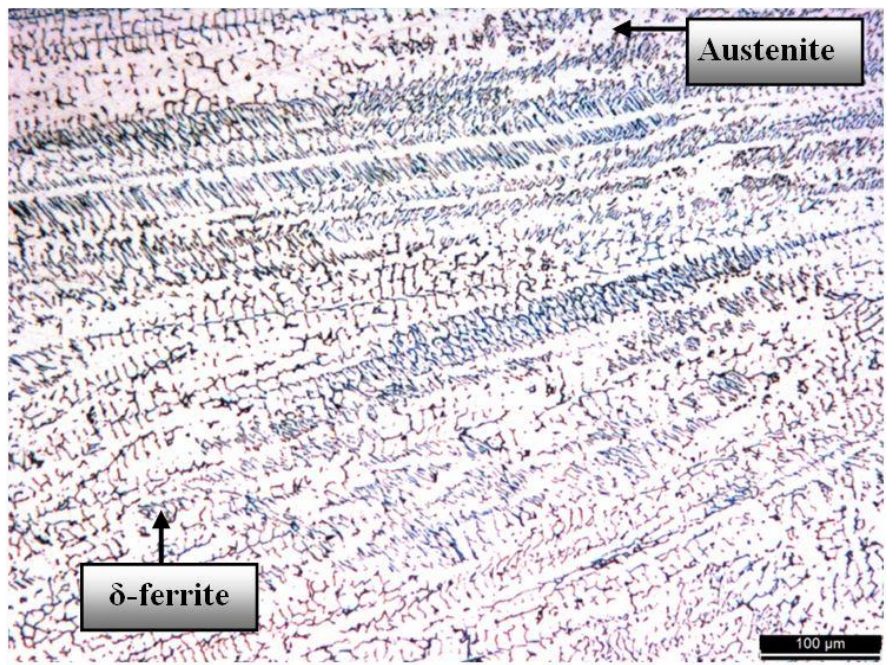

Figure 6. Weld metal microstructure of sample joined by ER2209 TIG Rod

\subsection{Phase Analysis}

Phase Estimation by Schaeffler Diagram

The equivalent values for 304L and 420 base metals are estimated according to Schaefflers Equations.

$\mathrm{Cr}_{\mathrm{Eq}, 304 \mathrm{~L}}=18.22+0.0545+1.5 \times 0.383+0.5 \times 0=18.9$

$\mathrm{Ni}{ }_{\mathrm{Eq}, 304 \mathrm{~L}}=8.01+30 \times 0.0276+0.5 \times 1.19=9.4$

$\mathrm{Cr}_{\mathrm{Eq}, 420}=13.35+0.0067+1.5 \times 0.235+0.5 \times 0=14.1$

$\mathrm{Ni}_{\mathrm{Eq}, 420}=0.142+30 \times 0.234+0.5 \times 0.629=7.6$

The equivalent values for ER312 TIG Welding Rod;

$\mathrm{Cr}_{\text {Eq, ER312 }}=0.7+0.2+1.5 \times 0.4+0.5 \times 0=31.5$

$\mathrm{Ni}_{\mathrm{Eq}}, \mathrm{ER} 312=8.8+30 \times 0.15+0.5 \times 1.6=9.9$ 
The equivalent values for ER316L TIG Welding Rod;

$\mathrm{Cr}_{\text {Eq,ER316L }}=18.2+2.6+1.5 \times 0.4+0.5 \times 0=21.4$

$\mathrm{Ni}_{\mathrm{Eq}, \mathrm{ER} 316 \mathrm{~L}}=12+30 \times 0.01+0.5 \times 1.7=13.2$

The equivalent values for ER2209 TIG Welding Rod;

$\mathrm{Cr}_{\mathrm{Eq}, \mathrm{ER} 2209}=22.7+2.6+1.5 \mathrm{x} 0.4+0.5 \mathrm{x} 0=26.7$

$\mathrm{Ni}_{\text {Eq, ER2209 }}=8.5+30 \times 0.01+0.5 \times 1.5=9.6$

According to Schaefflers diagram, 420 and 304L stainless steels have dominant martensitic and austenitic microstructures respectively as given in Figures 3-(a) and (b). ER312 TIG welding rod includes approximately 85\% delta-ferrite and remaining austenite by volume according to superimposed Schaeffler diagram given in Figure 7.

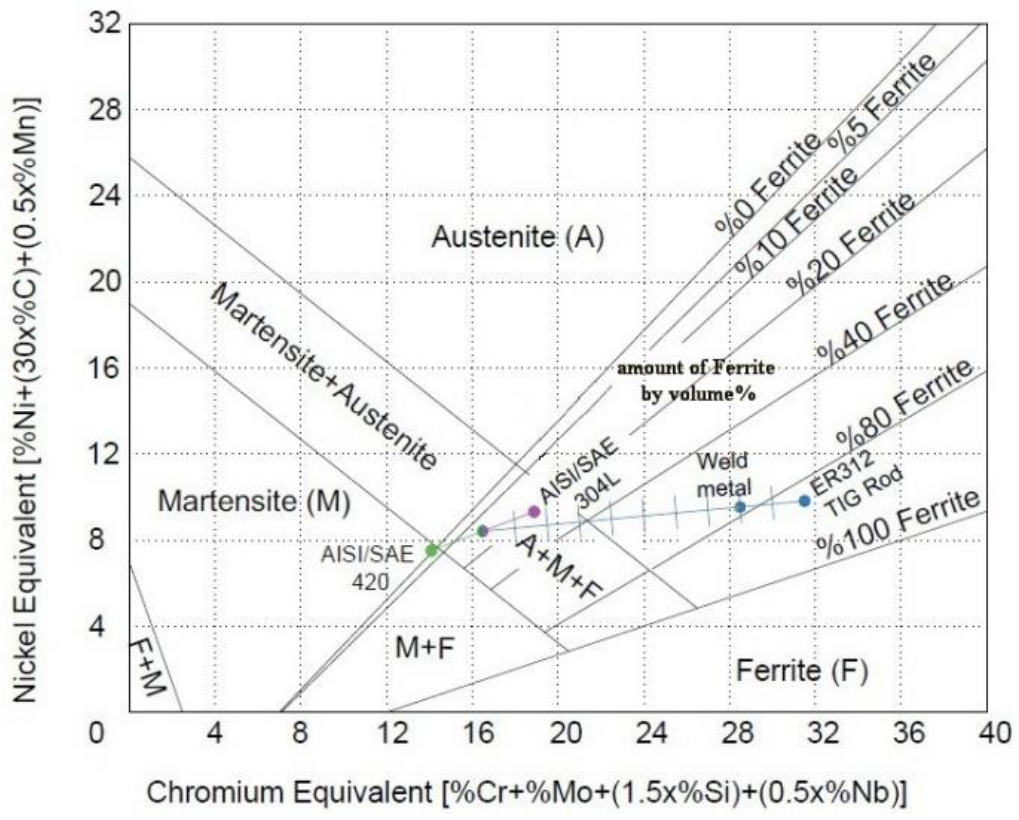

Figure 7. Phase locations of samples joined by ER312 TIG Rod plotted on Schaeffler Diagram

Weld metal of sample joined by ER312 TIG rod contains approximately 78\% delta-ferrite and remaining austenite in Figure 7. ER316L TIG welding rod and weld metal of sample joined by ER316L TIG rod both includes approximately 10\% delta-ferrite and remaining austenite as seen in Figure 8.

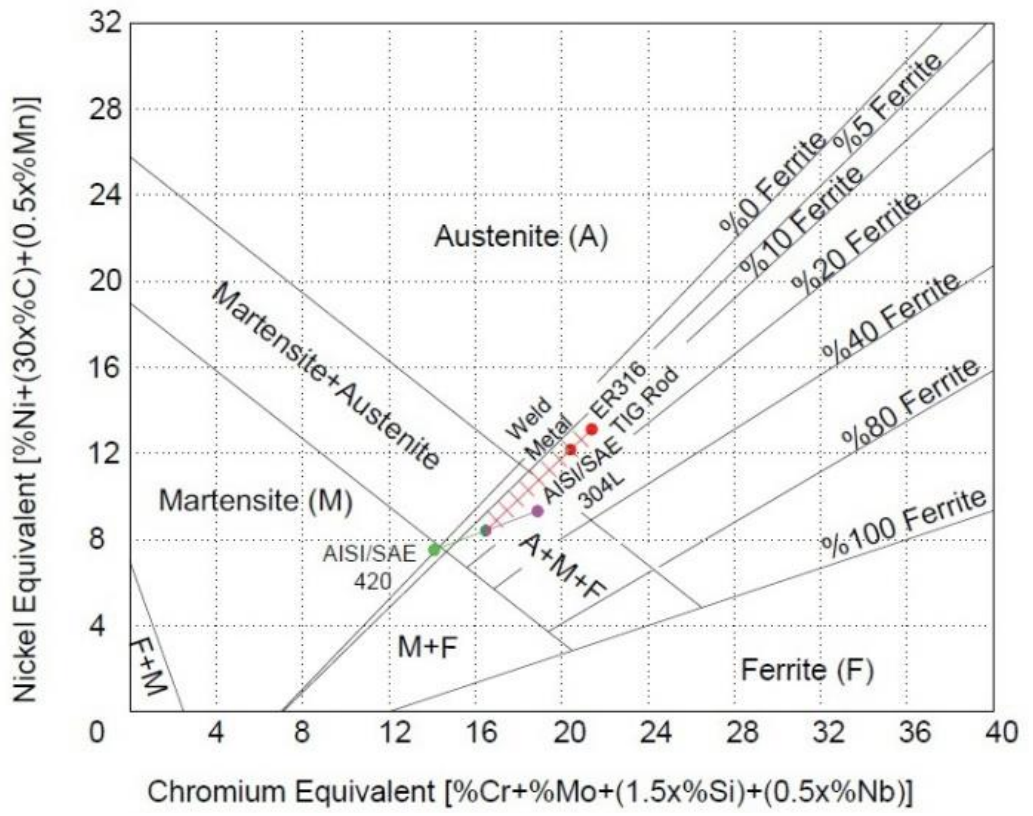

Figure 8. Phase locations of sample joined by ER316L TIG Rod plotted on Schaeffler Diagram 
ER2209 TIG welding rod includes approximately 66\% delta-ferrite and remaining austenite by volume according to Figure 9. Weld metal of sample joined by ER2209 TIG rod contains approximately 56\% delta-ferrite and remaining austenite in Figure 9.

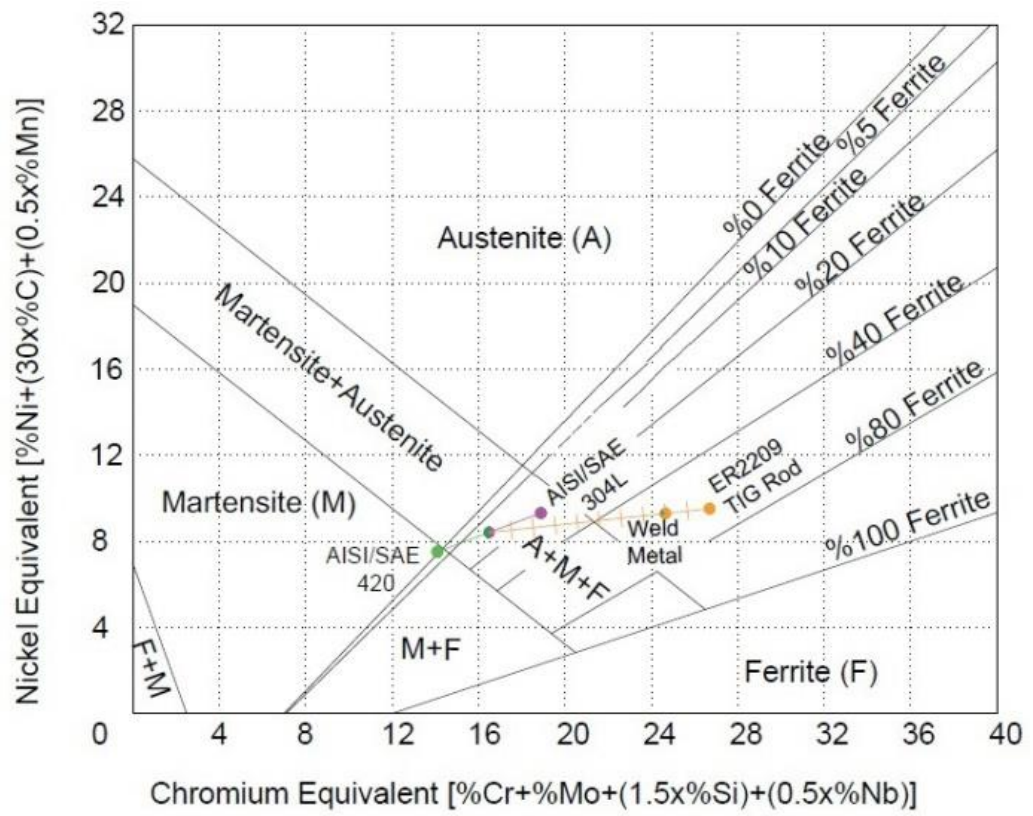

Figure 9. Phase locations of sample joined by ER2209 TIG Rod plotted on Schaeffler Diagram

Phase Estimation by Image Analysis

Image (phase) analysis was performed by 'Kameram' Software with metallographic examinations on electrolytically etched samples under $100 \mu \mathrm{m}$ magnification scaled micrographs.

Image Analysis of Base Metals

Image analysis result screen of 304L and 420 unwelded base metal is given in Figure 10. 304L base metal includes approximately $99 \%$ austenite (as yellow) and remaining minor amounts of delta-ferrite (as red) given in Figure 10-a.

420 base metal contains approximately $43 \%$ martensite (as blue), 31\% delta-ferrite (as red), 17\% carbides (as green) and $9 \%$ retained austenite (as yellow) given in Figure 10-b.

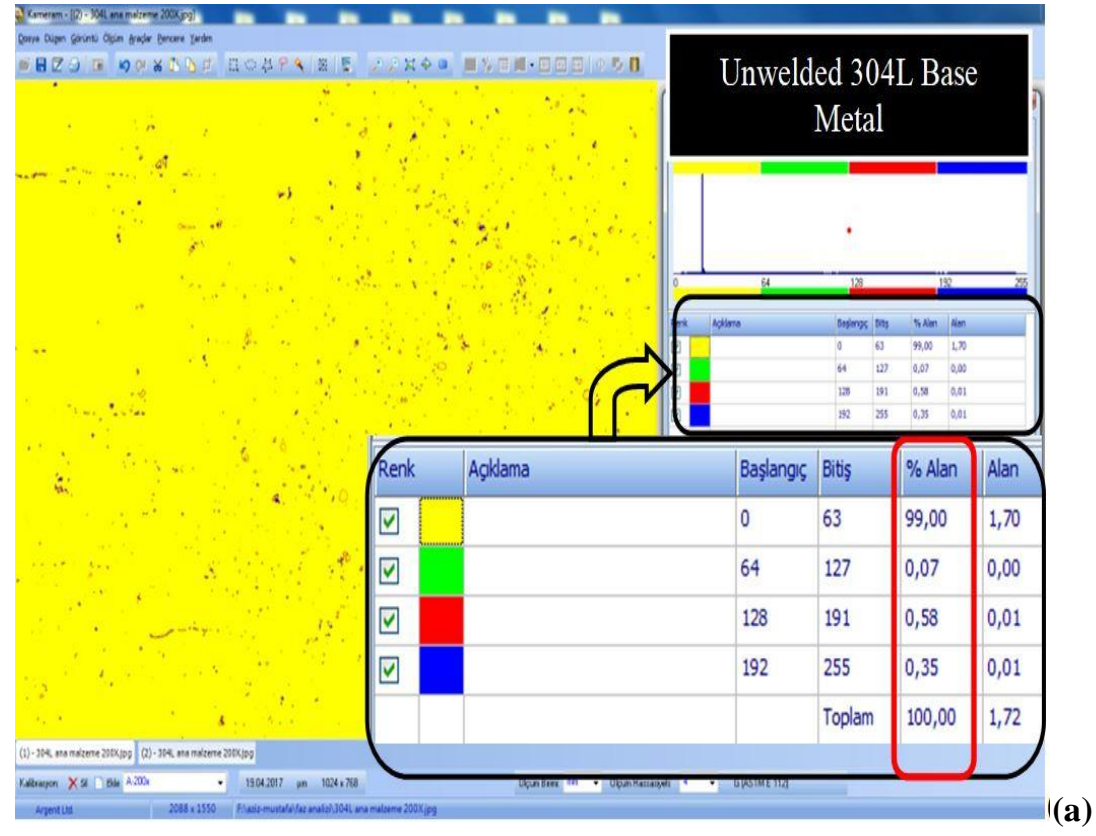

Figure 10. Image analysis of (a) 304L and (b) 420 base metal (continued) 


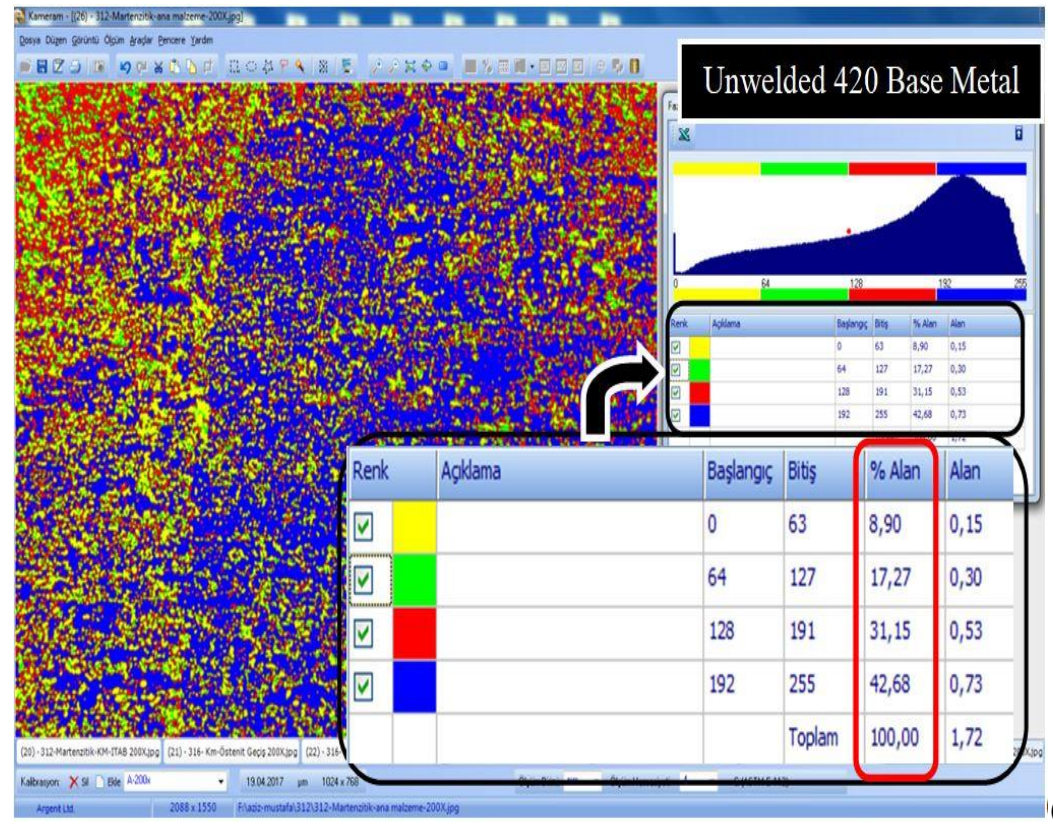

(b)

Figure 10. Image analysis of (a) 304L and (b) 420 base metal

Image Analysis of Weld Metals

The samples joined by 3 different TIG rods weld metal phase distribution is also analyzed by image analysis technique. Image analysis computational result screen views of weld metals are given in Figure 11.
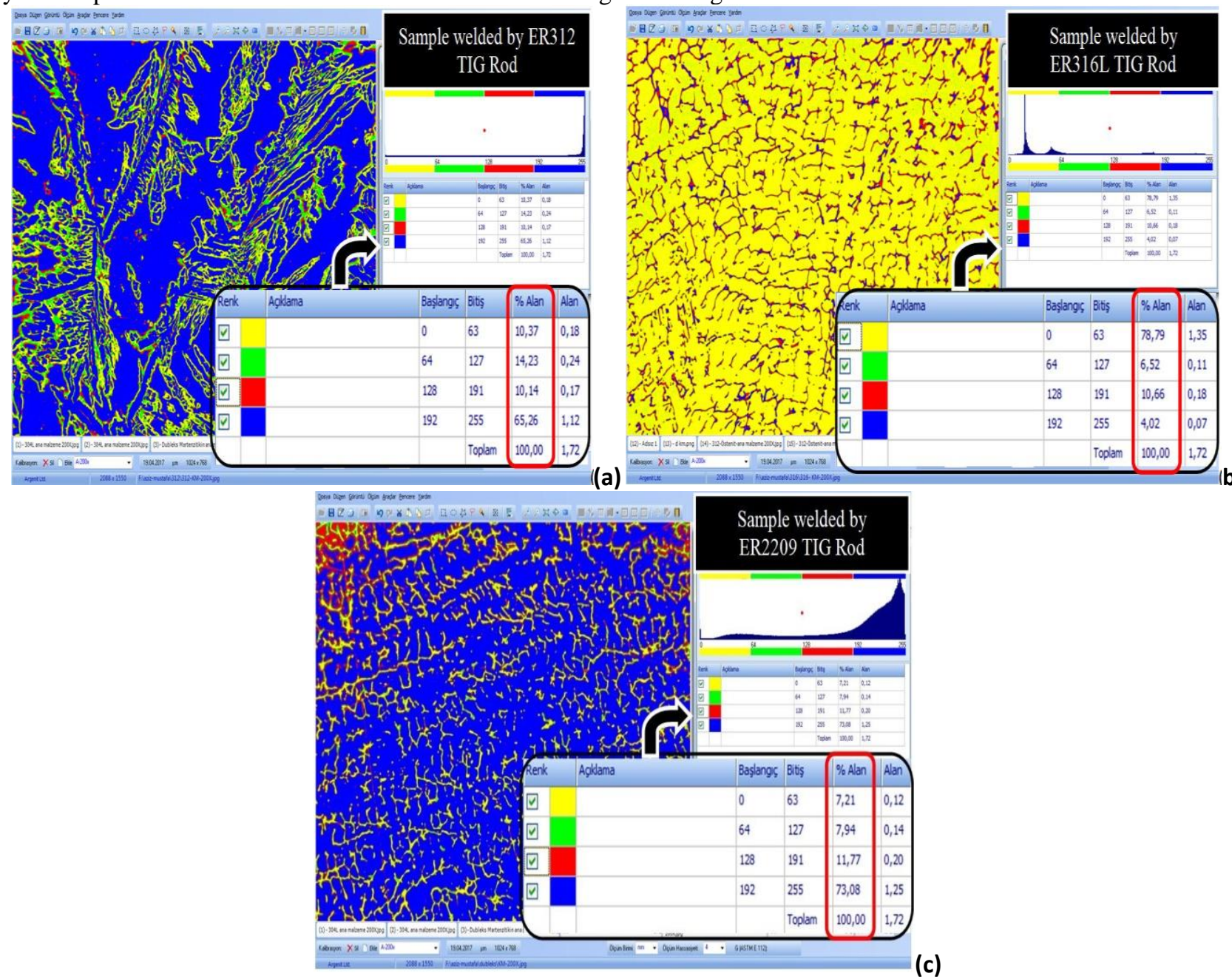

b)

Figure 11. Image analysis of samples weld metals joined by (a) ER312, (b) ER316L and (c) ER2209 TIG rods.

Weld metal of sample joined by ER312 TIG rod contains approximately 65\% delta-ferrite (as blue) and remaining amounts of austenite given in Figure 11-a. 
The software distinguishes the remaining phases but the remaining phase (in three different color scale) is only austenite in weld metal as detailed in microstructure of Figure 4. Weld metal of sample joined by ER316L TIG rod contains approximately 79\% austenite (as yellow) and remaining amounts of delta-ferrite seen in Figure 11-b.

The software distinguishes the remaining minor amounts of phases but the remaining phase (in three different color scale) is only delta-ferrite in weld metal as detailed in microstructure of Figure 5.

Weld metal of sample joined by ER2209 TIG rod contains approximately 73\% delta-ferrite (as blue) and remaining amounts of austenite given in Figure 11-c. The software distinguishes the remaining minor amounts of phases but the remaining phase (in three different color scale) is only delta-ferrite in weld metal as detailed in microstructure of Figure 6. The approximate weld metal phase content of samples joined by ER312, ER316L and ER2209 TIG rod estimated by microstructural image analysis are listed in Table 3.

Table 3. The approximate weld metal phase content of samples joined by ER312, ER316L and ER2209 TIG rod estimated by microstructural image analysis

\begin{tabular}{c|c|c|c}
\hline \multirow{2}{*}{ Phase } & \multicolumn{3}{|c}{ TIG Rod Type } \\
\cline { 2 - 4 } & ER312 & ER316L & ER2209 \\
\hline Delta- ferrite & 65.26 & 21.21 & 73.08 \\
Austenite & 34.74 & 78.79 & 26.92 \\
\hline
\end{tabular}

Phase distributions tested by Magnetic methods

Magnetic Phase analysis is applied on base metals and joined samples weld centerlines. 6 individual points at weld centerline is tested according to ISO 8249 and ISO 17655 standards. Magnetic phase testing detects mainly the ferromagnetic phases as martensite and delta-ferrite. Paramagnetic austenite phase is not detected in magnetic phase analyzing techniques. 304L austenitic stainless steel raw material (base metal) has exhibited $98 \%$ by volume of austenitic non-magnetic structure so that the remainder phase is magnetic delta-ferrite. Magnetic phase analysis of 420 martensitic stainless steel raw materials (base metal) was resulted in approximately $100 \%$ by volume that includes both major magnetic phases as delta-ferrite and martensite. The structure is whole magnetic. The welded samples magnetic phase detection results are given in Table 4.

Table 4. The approximate weld metal phase content of samples joined by ER312, ER316L and ER2209 TIG rod estimated by magnetic phase testing

\begin{tabular}{c|c|c|c}
\hline TIG Rod Type & ER312 & ER316L & ER2209 \\
\hline Vol. \% of magnetic & 61 & 10 & 45 \\
phases (delta- & 60 & 11 & 46 \\
ferrite+martensite). 6 & 58 & 13 & 43 \\
individual test points & 60 & 11 & 47 \\
on weld centerline & 60 & 11 & 37 \\
according to ISO & 63 & 12 & 38 \\
8249 and ISO 17655 & & & \\
& 1.633 & 1.033 & 4.23 \\
Standard deviation & 60 & 11 & 43 \\
Arithmetical average & 60 \\
\hline
\end{tabular}

Weld metal of samples joined by ER312, ER316L and ER2209 TIG rod has approximately 60\%, 11\% and 43\% magnetic phases of martensite and delta-ferrite by volume respectively as given in Table 4.

\subsection{Corrosion Tests}

Samples are immersed and reacted with corrosion test solution during 72 hours of time. Front and back sides of test samples before and after corrosion test are shown in Figure 12. 

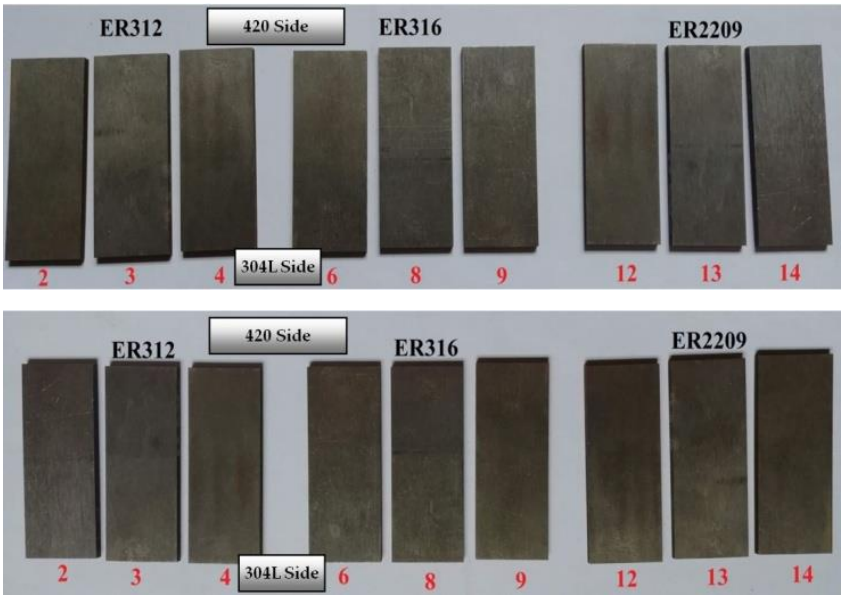

(a)
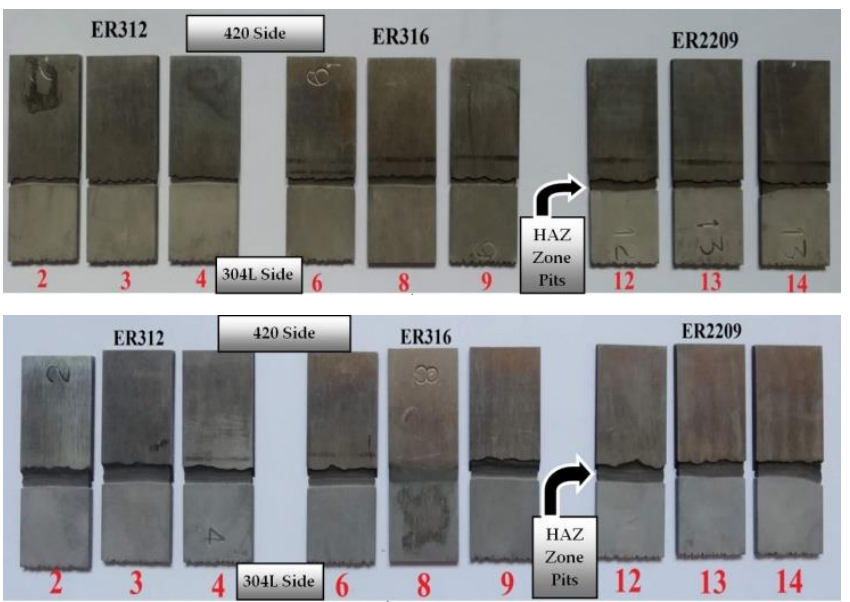

(b)

Figure 12. Front and rear side views of corrosion test specimens (a) before (b) after the test

Pits of corrosion like straight lines can be seen in Figures 12-b. The corrosion effect is detected especially on 420 stainless steel side of welded samples. 304L side exhibited a little corrosion view as compared to 420 side of all welded samples. Carbon content is the major factor in a stainless steel alloy to form detrimental corrosion products such as chromium carbides in a welded construction. The carbon content of 420 stainless steel plates is much higher than $304 \mathrm{~L}$ plates so that existing chromium element formed carbides with carbon element just after welding operation finishes on cooling. For estimating the corrosion rate, the total surface area of specimens is calculated by equation 4 (ASTM G48, 2015).

Total Surface Area $=2 \times[($ thickness $) \times($ length $)+($ thickness $) \times($ width $)+($ height $) \times($ width $)]$

As soon as the samples are completely cleaned and dried they are weighed again for three individual times by a $0.0001 \mathrm{~g}$ precision scale. Corrosion rate is defined in ASTM G48 as weight loss after the test and is estimated by equation 5.

\section{Corrosion Rate $=$ Total Wieght Loss $/$ Total Surface area of sample}

The result obtained from this equation must be smaller than $0.0001 \mathrm{~g} / \mathrm{cm}^{2}$ limit value in order not to be identified as sensitive to corrosion solution. Whether the result is bigger than limit value there should be sensitivity to test solution depending also at temperature that samples are exposed. ASTM G48 provides information whether material exhibits corrosion or not in such test solution.

Corrosion test results are given in Table 5. According to weight loss differences in Table 5, all of the welded specimens are affected from corrosion test solution so that it means all samples are sensitive to test solution at ambient laboratory temperatures of $22^{\circ} \mathrm{C}$. The arithmetical average values of corrosion test results are also given in Table 5 for simple comparison. For comparing the samples corrosion resistance values between themselves in units of corrosion rates (mm/year) ASTM G1 standard is also used.

Corrosion rate in ASTM G1 is estimated by equation 6 below.

Corrosion Rate $=(K \times W) /(A \times T \times D)$

Corrosion Rate: (mm/year) ,K: constant: $8.76 \times 10^{4}$ (mm/year), W: weight loss (gram), A: surface area $\left(\mathrm{cm}^{2}\right)$, T: time (hours), D: density $\left(\mathrm{gram} / \mathrm{cm}^{3}\right)$. 
Table 5. Corrosion test results of specimens

\begin{tabular}{|c|c|c|c|c|c|c|c|c|c|c|c|}
\hline $\begin{array}{c}\text { Sample } \\
\text { No. }\end{array}$ & \begin{tabular}{|} 
The \\
Samples \\
joined \\
by:
\end{tabular} & $\begin{array}{c}\text { Total } \\
\text { Surface } \\
\text { area } \\
\left(\mathrm{mm}^{2}\right)\end{array}$ & $\begin{array}{l}\text { Weight } \\
\text { loss } \\
\text { (gram) }\end{array}$ & $\begin{array}{c}\text { Arithmetical } \\
\text { average }\end{array}$ & $\begin{array}{l}\text { Standard } \\
\text { Deviation }\end{array}$ & $\begin{array}{l}\text { ASTM G48 } \\
<0,0001\end{array}$ & $\begin{array}{c}\text { Arithmetical } \\
\text { average }\end{array}$ & $\begin{array}{l}\text { Standard } \\
\text { Deviation }\end{array}$ & $\begin{array}{l}\text { ASTM G1 } \\
\text { (mm/year) }\end{array}$ & $\begin{array}{c}\text { Arithmetical } \\
\text { average }\end{array}$ & $\begin{array}{l}\text { Standard } \\
\text { deviation }\end{array}$ \\
\hline 2 & \multirow{3}{*}{$\begin{array}{l}\text { ER312 } \\
\text { TIG } \\
\text { Rods }\end{array}$} & 2346.6281 & 1.8826 & \multirow{3}{*}{1.9262} & & 2.6742 & & \multirow{3}{*}{0.062} & 0.0802 & \multirow{3}{*}{0.0816} & \multirow{3}{*}{0.002} \\
\hline 3 & & 2353.6000 & 1.9040 & & 0.006 & 2.6966 & 2.7208 & & 0.0809 & & \\
\hline 4 & & 2378.5998 & 1.9920 & & & 2.7916 & & & 0.0837 & & \\
\hline 6 & \multirow{3}{*}{$\begin{array}{l}\text { ER316L } \\
\text { TIG } \\
\text { Rods }\end{array}$} & 2370.5163 & 2.3860 & \multirow{3}{*}{1.8079} & & 3.3552 & & \multirow{3}{*}{1.533} & 0.1007 & \multirow{3}{*}{0,0762} & \multirow{3}{*}{0.046} \\
\hline 8 & & 2375.4446 & 0.5496 & & 1.091 & 0.7713 & 2.5403 & & 0.0231 & & \\
\hline 9 & & 2373.3414 & 2.4880 & & & 3.4944 & & & 0.1048 & & \\
\hline 12 & \multirow{3}{*}{$\begin{array}{l}\text { ER2209 } \\
\text { TIG } \\
\text { Rods }\end{array}$} & 2354.3833 & 1.8651 & \multirow{3}{*}{1.8784} & & 2.6407 & & \multirow{3}{*}{0.132} & 0.0792 & \multirow{3}{*}{0.0793} & \multirow{3}{*}{0.004} \\
\hline 13 & & 2377.6645 & 1.7924 & & 0.093 & 2.5128 & 2.6435 & & 0.0754 & & \\
\hline 14 & & 2373.9231 & 1.9778 & & & 2.7771 & & & 0.0833 & & \\
\hline
\end{tabular}

The sample joined with ER316L TIG rod exhibited the highest corrosion resistance values in ASTM G1 corrosion test. ER316L TIG rod has the lowest amounts of chromium among the other two TIG rods. Therefore, chromium element formed less amounts of carbides with 420 alloys carbon quantities. Besides, chromium tends to precipitate into delta-ferrite and martensite phases in order to form chromium rich carbides (Lippold \& Kotecki, 2005). The samples joined by ER316L TIG rod include the lowest amounts of delta-ferrite and martensite phases therefore they exhibited the better corrosion behavior among the other samples. The samples joined with ER312 TIG welding rods exhibited dendritic austenitic structure in weld metal as it includes no nitrogen, so that nitrogen makes the austenitic structure become more globular instead of a needle-like structure in the weld metal.

ER312 TIG rod has higher carbon and chromium amounts among other two TIG rod types. After welding operation with equal cooling effects weld metal gained the highest ratios of martensite and carbides as compared with other welded samples. The weld metal of sample welded by ER316L TIG rod has resulted in the highest amounts of austenite by the reason of having the highest amounts of austenite promoting elements as nitrogen, nickel, manganese and copper among the other TIG rods. The weld metal of sample welded by ER2209 TIG rod has exhibited the maximum amount of delta-ferrite owing to have the highest amounts of ferrite promoting elements such as chromium, molybdenum, silicon among the other TIG rods. Magnetic phase analysis results involve all magnetic phases as martensite and delta-ferrite together. Hence, micro-structural image analysis results differ from magnetic testing values. However, the results clarify the tendency of phase distribution ratios between each other.

The samples joined with ER316L and ER2209 TIG welding rods have exhibited globular austenitic microstructure in weld metal zones in consequence of including nitrogen in these TIG rods. According to ASTM G48 standard, all of the samples are affected from corrosion test solution at ambient laboratory temperature.

The estimated corrosion test results obtained from ASTM G48 must be smaller than $0.0001 \mathrm{~g} / \mathrm{cm}^{2}$ limit value in order not to be identified as sensitive to corrosion solution but in fact all corrosion test samples results are higher than this limit value. These is no chance to make comparison among these corrosion test results by ASTM G48 as these results only reveals whether the structure is sensitive to corrosion medium or not. Corrosion test results are also estimated by ASTM G1 standard for comparing all of the results among each other. The samples welded by ER316L TIG rod displayed the highest corrosion resistance among all of the three TIG rods as a result of having the lowest amounts of delta-ferrite, martensite and carbides so that these phases consumes the chromium amounts in case of forming detrimental compounds.

\section{Conclusions}

1. All of the welded samples are effected with test solution in corrosion tests.

2. The majority of corrosion effects are detected on 420 base metal sides within all samples. Little corrosion traces occured on $304 \mathrm{~L}$ base metals.

3. ER316L TIG welding rod can be selected in welding of dissimilar 420 and 304L stainless alloys for qualified joining related with better corrosion resistance among the ER312 and ER 2209 TIG rods used in experimental studies in this work.

4. ER2209 TIG welding rod can also be selected where globular grain structure is preferred as a result of the TIG rod including the maximum amounts of nitrogen for ensuring globular microstructure of weld metal with satisfactory corrosion properties according to test results. 
5. The carbon content of 420 martensitic stainless steel is higher than 304L alloy so that the higher corrosion effects are observed on 420 alloy sides of all welded samples. The higher carbon amount results in higher corrosion products by forming detrimental compounds such as chromium carbides in ferric chloride bearing solutions.

6. Phase disrributions of weld metals are analysed by three common methods but the results of image analysis was unlike with magnetic phase testing and Schaefflers diagram. The resolution accuracy of Kameram Image Analysis software is not adequate to determine the minor amounts of phases. Magnetic phase analysing method covers all magnetic phases together like martensite and delta ferrite e.t.c. but Schaefflers diagram and image analysis techniques determines all phases seperately. However, the results of three different phase analyzing methods are consistent within each other.

7. Increasing chromium amounts in TIG welding rods increased the delta-ferritic structure while nitrogen supported TIG rods promoted austenitic microstructure in weld metals of samples.

\section{Acknowledgements}

The authors express their thanks to Gazi University and Kırıkkale University, Metallurgical and Materials Engineering Departments Laboratories for their precious supports about testing instruments.

\section{References}

ASM Int. Handbook Committee, (2005). 'Properties and Selection: Wrought Stainless Steels’ ASM Handbook Vol. 2 , pp.1303.

ASM Metals Handbook Vol. 4, (1991). Heat treating, ASM International.

ASM Metals Handbook. Vol. 6, (1993). Welding Brazing and Soldering; ASM International. Almere, The Netherlands.

ASTM G1, (2017). Standard test methods for preparing cleaning and evaluating corrosion test specimens, ASTM International, Reapproved.

ASTM G31-12a, (2012). Standard guide for laboratory immersion corrosion testing of metals, NACE TM 0169, ASTM International.

ASTM G48, (2015). Standard test methods for pitting and crevice corrosion resistance of stainless steels and related alloys by use of ferric chloride solution, ASTM International, Reapproved.

ASTM E562-11. (2011). Standard Test Method for Determining Volume Fraction by Systematic Manual Point Count;ASM International: Almere, The Netherlands.

ASTM E1245 (2008). Standard Practice for Determining the Inclusion or Second Phase Constituent Content of Metals by Automatic Image Analysis; ASM International: Almere, The Netherlands.

AWS A5.9, (2017). 'Specification for Bare Stainless Steel Welding Electrodes and Rods', American Welding Society.

Corrosion of stainless steel weldments, ASM Handbook, Vol. 13-A. (2003). Corrosion: Fundamentals, testing and protection, ASM Int. p. 301-316.

Douglas W. Dietrich, (1997). Magnetically Soft Materials, Properties and Selection, Non-ferrous materials and special purpose materials, pp. 2226, ASM Handbook Vol. 2, ASM International.

EN ISO 8249. (2000). Welding-Determination of Ferrite Number (FN) in Austenitic and Duplex Ferritic-Austenitic Cr-Ni Stainless Steel Weld Metals; European Standard: Brussels, Belgium.

EN ISO 14343, (2017). Welding consumables, Wire electrodes, strip electrodes, wires and rods for arc welding of stainless and heat resisting steels, International Standard.

EN ISO 17655. (2003). Destructive Tests on Welds in Metallic Materials-Method for Taking Samples for Delta Ferrite Measurement; European Standard: Brussels, Belgium.

George F. et all, (2004). Metallography and Microstructures, ASM Metals Handbook Vol. 9, ASM International, p. 670-700, USA.

H.C. Dey, M. Ashfaq, A.K. Bhaduri, K.P. Rao, (2009). Joining of titanium to 304L stainless steel by friction welding, Journal of Materials Processing Technology, 209 5862-5870, Elsevier, doi: 10.1016/j.jmatprotec.2009.06.018.

H.M. Soltani, M. Tayebi, (2018). Comparative study of AISI 304L to AISI 316L stainless steels joints by TIG and Nd:YAG laser welding, Journal of Alloys and Compounds, 767 pp.112-121, doi: 10.1016/j.jallcom.2018.06.302. 
ISO 15614-1, (2017). Specification and qualification of welding procedures for metallic materials, Welding procedure test Part 1: Arc and gas welding of steels and arc welding of nickel and nickel alloys, Second Edition, International Standard.

Jastej Singh, A.S. Shahi, (2018). Weld joint design and thermal aging influence on the metallurgical, sensitization and pitting corrosion behavior of AISI 304L stainless steel welds, Journal of Manufacturing Processes, Volume 33, pp. 126-135,doi: 10.1016/j.jmapro.2018.05.004,

J.C. Lippold, D. Kotecki, (2005). Welding Metallurgy and Weldability of Stainless Steels, Wiley Interscience, pp. 56-57.

Jie Jiang, Dake Xu, Tong Xi, M. Babar Shahzad, M. Saleem Khan, Jinlong Zhao, Xinmin Fana, Chunguang Yang, Tingyue Gu, Ke Yang, (2016). Corrosion Science, 113 46-56, doi: 10.1016/j.corsci.2016.10.003.

Kou S. (2002). Welding Metallurgy, 2nd ed.Wiley Interscience Publications, Hoboken, NJ, USA.

M.M.A. Khan, L. Romoli, M. Fiaschi, G. Dini, F. Sarri, (2012). Laser beam welding of dissimilar stainless steels in a fillet joint configuration, Journal of Materials ProcessingTechnology, doi:10.1016/j.jmatprotec.2011.11.011.

N. Kumar, M. Mukherjee, A. Bandyopadhyay, (2017). Comparative study of pulsed Nd:YAG laser welding of AISI 304 and AISI 316 stainless steels, Optics \& Laser Technology, Elsevier, 88 24-39, doi: 10.1016/j.optlastec.2016.08.018.

Pierre R. Roberge, (2000). Handbook of Corrosion Engineering, Chapter 8, Materials Selection, McGraw Hill Publications, p. 716. 